\title{
THE MODEL OF SLOVAK RAILWAY STRATEGY
}

Rail transport plays a key role in transport services within a domestic and international scope. In the scope of social and economic changes and the dynamically developing transport sector, it is the task of railways to analyse and programmatically prepare its management.

In the context of European and national traffic policy the strategy of Railways of the Slovak Republic (ZSR - Zeleznice Slovenskej republiky) identifies the need for successful technological and company development in the coming decades.

This short paper of ZSR strategy contributes to better knowledge and a positive presentation of the direction of ZSR towards bodies of state administration and partner organizations within a domestic and international scope.

Keywords: Strategic Analysis, mission, vision, SWOT, priorities, main supporting process.

\section{Introduction}

ZSR were founded on January 1, 1993 by a decision of the Government of the Slovak Republic on establishment of a state company following the split-up of the Czechoslovak Federal Republic and thusthe split-up of the Czech and Slovak State Infrastructure into two independent entities.

As of January 1, 2002 ZSR was further divided into two independent entities according to the ZSR Transformation and Re-organisation Project - into ZSR and Zelezničná spoločnost, a.s.

ZSR is an infrastructure manager - it provides transport services as well as other related activities in the line with the state transport policy and market demands.

Since January 1, 2002 the main function of ZSR is as follows:

- management and operation of railway infrastructure,

- provision of operation-related services,

- founding and operating of railway, telecommunication and wireless networks,

- construction, regulation and maintenance of railway and funicular infrastructure,

- other business activities as recorded in the Commercial Register.

\section{The starting points for strategy}

The strategy of ZSR for the following decades is directed at the improvement of business activities, modernization of the traffic control system and infrastructure during the ongoing transformation so that the prescribed goals in the transformation and restructuring project of ZSR can be fulfilled. The objectives of traffic policy of the Slovak Republic for railway traffic have been established until the year 2015 .

Stefan Hittmar

Faculty of Management Science and Informatics, University of Zilina, Slovakia, E-mail: hittmar@fria.utc.sk
The traffic policy of the European Union (EU) presented in the White Book and subsequent legislative activities markedly support railway transport. The first aim incorporates the aggregate of targets and supporting measures for the increase of activities of railway companies in today's market conditions. The second labourlaw-oriented objective is the relationship between the state and transport companies. Increase in railway traffic safety together with interoperability are the pillars of the integrated European railway system.

The external economic legal environment and internal conditions of ZSR influence the following SWOT analysis:

The SWOT analysis for strategy

Tab. 1

\begin{tabular}{|l|l|}
\hline \multicolumn{2}{|c|}{ Internal conditions } \\
\hline $\begin{array}{l}\text { Strengths: } \\
\text { The rail system of ZSR forms part } \\
\text { of EU development plans and } \\
\text { these activities are also included in } \\
\text { the financing of EU; part of the } \\
\text { network is included into European } \\
\text { transport corridors. Railway } \\
\text { transport contributes significantly } \\
\text { to transport safety and represents } \\
\text { the most environmentally friendly behind in railroad moderni- } \\
\text { zation and low interoperability } \\
\text { mainly in railroad interconnection } \\
\text { transportation. }\end{array}$ & \\
\hline \multicolumn{2}{|c|}{ External condith EU states. } \\
\hline $\begin{array}{l}\text { Opportunities: } \\
\text { The new structure of prices for indi- } \\
\text { vidual segments; change of organi- } \\
\text { zation, management and marketing; } \\
\text { expected increase of railway } \\
\text { transport capacity influenced by } \\
\text { the transport policy of the EU; the } \\
\text { access of new foreign investors in } \\
\text { the Slovak Republic are expected. }\end{array}$ & $\begin{array}{l}\text { Threats: } \\
\text { transport; competition of } \\
\text { neighbouring railway lines and } \\
\text { slow progression of ZSR railroad } \\
\text { infrastructure. }\end{array}$ \\
\hline
\end{tabular}




\section{Strategic vision for ZSR}

To transform ZSR on the basis of its mission to be an effective market oriented company, under the conditions of regulated economic competition and European railroad integration with strong orientation to the customer in the given geopolitical area.

\section{Mission of ZSR}

To create an integrated offer of railroad infrastructure capacities and services for the transport of persons and goods based on the highest safety and effectiveness, reliability and environmental acceptability.

The main priorities of ZSR as the infrastructure manager include

- trading activities focused on transport routes trading,

- process of transport organisation and management,

- modernisation of the infrastructure to support the ZSR's commercial orientation and efficiency,

- ongoing transformation of ZSR to a market-oriented entity in the conditions of regulated economic competition.

\section{Model of strategy for ZSR}

On the basis of being performed an analysis, defining a vision and mission of ZSR the strategy can follow. The basic model of strategy is an alternative which consists of priorities and main support processes, Fig. 1.

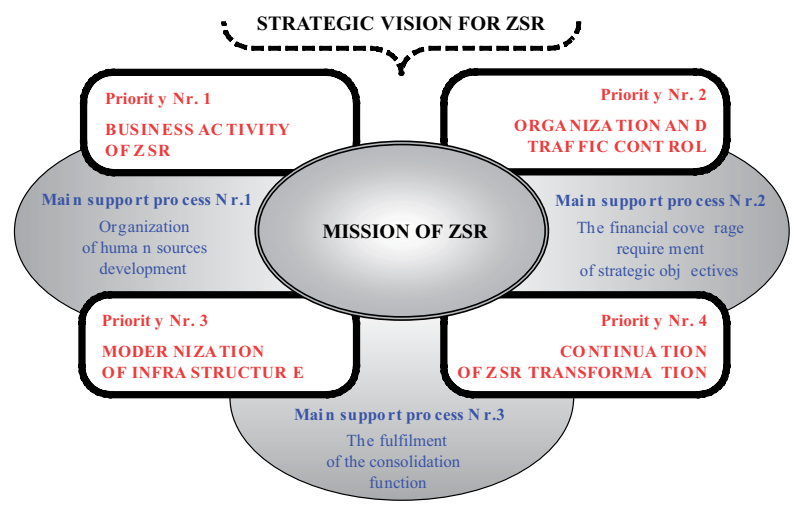

Fig.: 1. The basic model of strategy

\section{Priority Nr. 1 - Business activity of ZSR}

The offer and sale of ZSR train paths

The offer and sale of ZSR train paths increases the standard of offered services, both on a material and technological base. ZSR will provide high-quality delivery routes and prompt response to market needs. ZSR will build up customer loyalty and an individual attitude to different market segments. Today, total number of customers is 19 .

\section{Trade with energies}

The reduction of total expenses in the purchase of power-producing media, increased rate of profits from trade with energies by the construction of a business-energy control station of ZSR and the provision of high-quality services for customers in the areas of energy supply.

Property management

An active approach to property handling and working-out of planning process for the prognostication of sale, demand and property leasing.

The offer of telecommunication services

Aimed at individual organisation units is to operate the sales of telecommunication services as an alternative telecommunication operator

\section{Priority Nr. 2 - Organization and traffic control}

Management of transport operation of the ZSR railway system with the assistance of advanced railway technology will enable the application of a new system for dispatcher's control of ZSR transport. The modernisation of railway lines will enable centralisation of the operating staff of railway stations and the railway network, which will lead to the centralisation of dispatcher control at the corresponding corridor resulting in a reduction of mainly operating staff.

ZSR will create technical and organizational conditions for ensuring the customer's requirements in the activities of the infrastructure manager, mainly regarding accuracy and quality. The implementation of the compensative system for caused delays between carriers and the infrastructure management will mainly contribute hereto.

In co-operation with carriers, ZSR will accentuate passenger transportation the construction of train diagrams in order to achieve travelling without long latency periods. The publication of different forms of a railway guide will enable the travellers' easy access to information about the necessary train connections.

Within freight transportation ZSR will create conditions for a stable GVD (train traffic diagram). In collaboration with carriers and neighbouring countries, idle time at cross-border stations will be reduced.

Activities of train formation (a network of formation yards) will be adapted to the required capacity. ZSR will modernise these formation yards appropriately.

ZSR will monitor the business performances of railway private sidings and evaluate the efficiency of station yards during the modernisation and reconstruction of the railroads. 
Priority Nr. 3 - Modernisation of infrastructure to support the business orientation and effectiveness of the company

ZSR must accelerate the modernisation of railways included in the Pan - European railways transport system IV; V; VI; these railroads form part of the TEN transport network. The important Bratislava railway junction within the framework of the Vienna Bratislava interconnection makes increasing demands on the transport capacity of passenger and freight service.

The new infrastructure has to be utilised so that the provision of infrastructure services will also yield business growth for the company.

Modernisation of the railway transport system for the speed limit $160 \mathrm{~km} / \mathrm{h}$ and the fulfilment of other parameters in AGC and AGTC agreements arise from the need of ZSR to be internationally accepted.

ZSR will implement:

ERTMS - European Railway Traffic Management System in accordance to the strategic EU/UIC technological projects,

ERTMS - European Railway Traffic Management System,

ETCS - European Train Control System,

GSM-R - Global System Mobil Railway,

GALILEO - ZSR will be connected to the railway satellite system applications after corresponding analyses.

The implementation strategies for these systems will be elaborated according to EU legislation.

Priority Nr. 4 - Continuation of transportation a market-oriented company under the conditions of regulated economic competition and European railway integration

The changeover process of the control system and organization belongs to one of the most important steps on the road to a more effective transport company in the long-term transformation process of ZSR. The definition of two regional directorates for the management of railway transport and the division of infrastructure for railway maintenance will enable a decrease in the number of workers and accurate economical breakdown of railway transport costs.

The legal form of ZSR as a state enterprise remains unchanged in the long-term strategy horizon.

The integration of ZSR into European structures, internationalisation of the railway transport market and creation of a European single railway system requires the membership of ZSR in strategic associations like UIC, CER, OSŽD, G4 - Regional Corporation, RailNetEurope and project ERIM TREND etc.

The implementation of EU legislation (Technical specifications for interoperability) into the system of internal technical norms of ZSR. This process is understood as harmonisation of the legislature of the Slovak Republic in the field of the legal status of ZSR as manager of the railway infrastructure on the level of EU legislature. This means a change in the relationship between the state and ZSR, provision of financial resources and the achievement of financial equilibrium and company stability.

Priority support process Nr.1: Ensurance of human resources development

The objective of human resources strategy is preparation for the competitive environment which requires system changes in the organisational processes with the accent on:

$=$ changes in the behaviour of employees,

= changes on the level of work specialisation,

$=$ increase in their professional level,

$=$ increased level of identification with the

= company and with customer oriented policy.

The target groups of human resources strategy:

$=$ managers:

$=$ other employees

The primary purpose of personnel strategy includes the following areas:

= optimisation of human resources,

= policy for workers who have been released from the company,

$=$ increase in competence and performance of the employees,

$=$ decrease in the average age of employees,

= complex incorporation of knowledge taken from railway psychology into railway development,

= implementation of the latest knowledge and experience taken from modern personnel management; improvement of work and social conditions of ZSR employees,

$=$ establishment of career development system and system of personnel reserves,

= development of internal communication system,

$=$ improvement of managerial skills,

= regulation of relations with trade union central offices,

$=$ preventive health care for selected groups of employees.

Priority support process Nr.2: Financial ensurance for the realisation of strategic objectives

The provision of financial resources is the basic condition for the implementation of strategic objectives. The scope of possibilities for procuring financial resources is limited:

= legal status of ZSR and related legislation,

= financial situation of ZSR,

$=$ political decisions of the government for financing ZSR.

Financial ensuring of long-term strategic objectives of ZSR:

$=$ alternative financial model for the attainment of long-lasting economisation of ZSR,

$=$ multi-source financing of long-term strategic projects,

$=$ transformation of financial relations between the state and ZSR in accordance with the acquis communnautaire EU, 
$=$ sufficient financial resources needed for the modernisation of railway transport lines and technical equipment for other railway lines.

The financial model developed for strategy purposes analyses several scenarios for the development of ZSR according to different inputs and financial contribution from the state or the need to draw credit.

Priority support process Nr.3: Rational fulfillment of the consolidating of ZSR

The success of fulfillment of consolidating function is dependent on the reciprocal relationship between the state represented by Ministry of Finance of SR, Ministry of Transport, Posts and Telecommunications and ŽSR and fulfillment of costs purpose.

Solution of fulfillment the consolidation function of ZSR is based on decree of government. There are annually corrections of control mechanism on base of economic result for sections: economy, employment and social field.

The fulfillment of this objective is closely connected with the continuation of transformation of financial relations between the state and ZSR including the solution of the consolidating function.

The basic prerequisite is high-quality financial management of the company. Its basis was laid by the new organizational structure and within the gradual process of change founded on the basis of a procedure- oriented company.
This process include risks and unresolved problems:

Political risks

- the accomplishment of the ZSR mission and ensuring the fulfillment of strategic objectives is significantly subject to political decisions, concretized by the supportive measures of state administration and legislation.

Economic risks

- risks resulting from the transformational process,

- risks from indeterminateness of macro-economic development of the Slovak Republic,

- risks from liberalisation of the transport market and related branches,

- financial strategy risks (financial and investment risks).

Unresolved problems in the internal organisation of ZSR include - restructuring of ZSR,

- the management of ZSR in full extent from implementation of strategy to the company, acceptation of strategy as the basis of the company plan, updates on the basis of feedback.

Connected risks of consolidation function of ZSR

- ensuring balanced management,

- establishment of economic qualified costs,

- regulation system of payment for transport path and its impact on ZSR economy results and state budget,

- completion of process capitalizing asset into ZSR basic capital,

- settlement of debts (principal + interest) from credits with state guarantee,

- justifying with property resulting from transformation process of ZSR.

\section{References}

[1] Internal sources of General Direction ZSR, Bratislava, 2006, 2007 